\title{
PILIHAN HUKUM WARIS BAGI ORANG DI INDONESIA BERAGAMA ISLAM
}

\section{Oleh :}

\section{Bambang yunarko}

\begin{abstract}
Authoritative give and break the heir case for Indonesia people which believe in the Islam based interest of obsolut Religion Court, Section 49 sentence 1 Number Law 7 Year 1989, residing in Religion Court, while choice of hereditary law for Indonesia people which believe in the Islam pursuant to number 2 sixth paragraph public Clarification of Number Law 7 Year 1989 can only be done outside Jurisdiction Body.
\end{abstract}

Keyword : Hereditary Law Choice, People In Indonesia Believe in Islam.

\section{PENDAHULUAN}

Sebagai salah seorang anggota masyarakat, kalau kita berbicara tentang seseorang yang meninggal dunia arah dan jalan pikiran kita tentu menuju kepada masalah warisan.

Apabila seorang manusia selaku anggota masyarakat selama masih hidup mempunyai hak dan kewajiban terhadap orang lain serta harta benda yang berada dalam kehidupan masyarakat.

Dengan demikian apabila seseorang yang menjadi anggota masyarakat itu meninggal dunia, baik karena sudah tua atau sakit maupun kecelakaan, maka hubungan hukum seseorang yang meninggal dunia itu tidak lenyap begitu saja karena ia masih mempunyai sanak saudara yang ditinggalkan.

Dari pemaparan di atas, tentu saja hukum diperlukan untuk hadir di tengah masyarakat guna mengatur kepentingankepentingan dalam masyarakat itu dapat diselamatkan. Hal ini sejalan pula dengan tujuan hukum, yaitu untuk mengatur dan membahagiakan masyarakat. Disinilah muncul pengertian "Hukum Kewarisan", yaitu suatu peraturan tentang warisan dan harta peninggalan dari orang yang telah meninggal dunia. (Oemar Salim, 2000:2.)

Pada umumnya masyarakat menghendaki adanya suatu peraturan yang menyangkut warisan dan harta peninggalan dari orang yang telah meninggal dunia. Wirjono Prodjodikoro, memberikan batasan-batasan mengenai warisan, antara lain: (Oemar Salim, 
2000:4)

a. Seorang yang meninggalkan warisan pada saat orang tersebut meninggal dunia;

b. Seorang atau beberapa orang ahli waris, yang mempunyai hak menerima kekayaan yang ditinggalkannya;

c. Adanya harta warisan.

Sesungguhnya dalam kehidupan masyarakat di dunia ini memiliki kekeluargaan yang berbeda-beda. Dari sinilah keadaan warisan dari masyarakat itu tergantung dari masyarakat tertentu yang ada kaitannya dengan kondisi kekeluargaan serta membawa dampak pada kekayaan dalam masyarakat. Menurut asser meyers, bangsa-bangsa di dunia ini mula-mula tidak mengenai hak milik perseorangan atas barang-barang kekayaan melainkan hanya mengenai milik bersama dari suatu suku bangsa dan keluarga, disini tidak ada tempat bagi peraturan hukum dalam arti yang sebenarnya, karena dengan meninggalnya seseorang barang yang ia miliki tidak beralih ke ahli waris, melainkan hanya berpindah kepengurusan barang tersebut kepada orang lain yang masih hidup.
Untuk menguatkan pendapat asser meyers tersebut di atas penulis mengaitkan dengan kehidupan jaman nenek moyang kita yang sistem kehidupan keluarga yang mempengaruhi sistem kewarisan di Indonesia. Untuk orangorang Indonesia asli ada yang tidak memiliki sifat kekeluargaan, tetapi ada juga di beberapa daerah yang memiliki aneka ragam sifat kekeluargaan, menurut hukum adat sistem I kekeluargaan yang perlu diperhatikan ada 3 (tiga), yaitu: (Oemar Salim, 2000:6)

1. sistem patrilinel

2. sistem matrilineal

3. sistem parental/ bilateral Andanya perbedaan dari ketiga macam sifat kekeluargaan, maka dapat dikatakan bahwa sifat-sifat kekeluargaan tersebut sangat mempengaruhi pada sifat kewarisannya. Jika ketiga macam sifat kekeluargaan yang terdapat pada orangorang Indonesia asli, maka bila dipandang keseluruhannya terdapat juga sifat kekeluargaan dari orang Indonesia keturunan Tionghoa dan Eropah yang lebih tunduk pada hukum Burgerlijk Wetboek (selanjutnya disebut BW), disini akan terlihat persamaan dari sifat kekeluargaan dan warisan antara orang-

Pilihan Hukum Waris Bagi Orang Di 275 
orang Indonesia asli dengan sifat kekeluargaan orang-orang Indonesia keturunan Tionghoa dan Eropah. Letak perbedaannya adalah adanya pasal 1066 BW, yang ada dalam hukum adat diantara orang-orang Indonesia asli. Pasal 1066 BW menetapkan adanya hak mutlak dari masing-masing para ahli waris, apabila pada suatu saat menuntut pembagian dari harta warisnya.(Oemar Salim, 2000:8)

Pada hukum adat untuk orangorang Indonesia asli kadang-kadang harta warisan itu masih utuh dan tidak menjadi suatu keharusan untuk dibagikan pada ahli warisnya. Orang Indonesia asli yang tunduk pada hukum adat semata-mata karena sebagian besar mereka adalah pemeluk agama Islam, maka dari itu pengaruh peraturan warisan yang terdapat dalam hukum Islam kadang-kadang sangat berpengaruh.

Peraturan warisan dalam hukum Islam jelas berbeda dengan peraturan warisan agama Kristen, Hindu maupun agama lainnya. Penduduk Indonesia dari keturunan Arab pada umumnya mempergunakan peraturan warisan dari hukum Islam atau orang-orang Indonesia asli yang beragama Islam dan taat pada hukum Islam.

Pada masa penjajahan dahulu Pemerintah Hindia Belanda dengan politik hukumnya membagi penduduk di Indonesia berdasarkan pasal 163 Indische Staatsregeling (selanjutnya disebut IS) atas 3 golongan yaitu :

a. Golongan Eropah;

b. Golongan Bumi Putera;

c. Golongan Timur Asing.

Bagi ketiga golongan penduduk ini berlaku hukum perdata yang berbeda dan konsekuensinya lebih lanjut dalam bidang kewarisan juga berlaku bermacam-macam hukum waris. Bagi golongan Eropa tunduk pada hukum Eropa, bagi golongan Bumi Putera tunduk pada hukum Adat dan bagi golongan Timur Asing tunduk pada hukum Adat Timur Asing.

Bagi golongan Eropah dan golongan Timur Asing, berkaitan dengan ahli warisnya ada 2 cara yaitu :

a. Sebagai ahli warts menurut undang-undang;

b. Sebagai ahli waris karena ditunjuk dalam Surat Wasiat.

Sedangkan golongan Timur Asing dibagi dalam 2 bagian yaitu :

a. Timur Asing Tionghoa 
b. Timur Asing Bukan Tionghoa. Bagi golongan Timur Asing bukan Tionghoa misalnnya orang Arab, maka ketentuan mengenai "siapa ahli waris" pada umumnya dipengaruhi oleh Hukum Islam. Oleh karena hukum adat mereka boleh dikatakan pada umumnya sama dengan hukum yang berlaku di negara Arab, sekiranya hukum Agama Islam berlaku penuh atau hampir penuh. Sedangkan orang-orang Indonesia Asli tak terdapat satu sifat kekeluargaan melainkan di pelbagai daerah ada pelbagai sifat kekeluargaan yang dapat dimasukkan dalam 3 macam golongan yaitu :

1. Sistem matrilinel;

2. Sistem patrilineal;

3. Sistem parental/ bilateral.

Dari uraian di atas, maka hukum waris yang berlaku di Indonesia, bersifat pluralisms, yaitu:

a. Hukum waris adat yang berlaku bagi orang-orang Indonesia asli daribermacam-macam daerah yang masih ada kaitannya dengan ketigasifat kekeluargaan, yaitu, sifat kebapakan, sifat keibuan dan sifat kebapak-ibuan.

b. Hukum Islam yang berlaku bagi orang-orang Indonesia asli atau keturunan Arab yang beragama Islam,

c. Hukum waris Burgerlijk Wetboek (BW) buku II titel $12 \mathrm{~s} / \mathrm{d} 18$ pasal $830 \mathrm{~s} / \mathrm{d}$ pasal 1130 yang berlaku bagi orang-orang Indonesia keturunan Tionghoa atau Eropa.

Dengan masih berlaku tiga sistem hukum di bidang kewarisan di Indonesia yaitu sistem hukum waris adat, sistem hukum waris Islam dan sistem hukum waris BW, hai ini menimbulkan konsekuensi hukum kepada para pihak, apabila terjadi perselisihan sengketa kewarisan utamanya kepada orang-orang Indonesia asli yang beragama Islam dalam kaitannya dengan pilihan hukum yang dipergunakan untuk menyelesaikan sengketa kewarisan.

\section{RUMUSAN MASALAH}

Berpangkal tolak pada uraian latar belakang masalah di atas, maka perlu di analisa tentang Apakah orang Indonesia yang beragama islam dapat melakukan pilihan hukum dalam menyelesaikan sengketa pembagian waris?

PEMBAHASAN

\section{Hukum Waris Menurut Hukum Islam}


Hukum waris menurut Hukum Islam, arti waris dalam Hukum Islam berasal dari bahasa Arab yang berarti peninggalanpeninggalan yang ditinggalkan oleh seorang yang meninggal dunia. Hukum waris itu juga dinamakan Fereidh yang artinya pembagian tertentu.(Tamakiran, $2004: 84)$

Tujuan dari hukum waris Islam adalah mengatur cara-cara membagi harta peninggalan agar supaya dapat bermanfaat kepada ahli waris secara adil dan balk. Oleh karena harta peninggalan atau harta pusaka itu adalah hak milik dari yang meninggalkan balk yang is dapat sendiri, secara usaha perseorangan atau pemberian secara sah dari orang lain atau warisan-warisan turun temurun, maka agama Islam menganggap bahwa pengatur warisan itu adalah urusan keluarga ahli waris, tidak dapat dicampuri oleh orang luar yang tidak termasuk anggota keluarga yang berhak.

Dalam pada itu agama Islam mengatur cara-cara warisan itu adalah berazaskan keadilan antara kepentingan anggota keluarga dan kepentingan agama dan masyarakat. Tinjauan lebih lanjut bahwa unsur-unsur kewarisan dalam Islam itu meliputi untuk jaminan- jaminan kehidupan rokhaniah dan jasmaniah, sebab sebelum orang yang berkepentingan meninggal dunia dianjurkan mengadakan wasiat ialah amanat pemberian dari sebagian harta peninggalannya untuk kepentingan masyarakat, sehingga yang berwasiat itu mendapat pahala dari Tuhan Yang Maha Esa. Hukum waris Islam tidak meneruskan hukum adat bangsa Arab, bahkan banyak yang diubah, ditambah dan disempurnakan.

Contoh : Berhubung dengan adanya sifat kekeluargaan kebapaan di tanah arab yang mendapat bagian hanya :

1. Anak laki-laki;

2. Cucu laki-laki;

3. Anak dari anak laki-laki;

4. Saudara laki-laki;

5. Anak laki-laki dari saudara laki-laki;

6. Ayah;

7. Kakak dan sebaginya.

Dari hal tersebut di atas, dapat diketahui bahwa pembagian warisan semata-mata hanya kepada garis keturunan laki-laki saja. Dari pada hukum adat Arab lama itu telah banyak diubah oleh hukum Islam, oleh Al Qur'an 
ditambahkan selaku ahli waris adalah :

1. Anak perempuan;

2. Cucu perempuan;

3. Janda perempuan;

4. Ibu dan nenek;

5. Janda laki-laki;

6. Saudara perempuan baik yang sebapak atau seibu, maupun yang hanya sebapak atau hanya seibu saja.

Maka Islam tidak hanya memberi warisan kepada pihak suami atau isteri saja, tetapi juga dari kedua belah pihak balk garis ke atas, garis ke bawah, atau garis ke sisi. Dengan alasan-alasan demikianlah maka hukum waris Islam itu tidak bersifat patrinial tetapi hukum waris itu bersifat bilateral individuel menurut sistim Al Qur'an, artinya bilateralnya ditentukan dengan porsi secara individu dengan uan-ketentuan menurut AI Qur'an secara maksimal. Maka nyatalah hukum waris Islam menetapkan ahli waris pria dan ahli waris wanita sedemikian rupa, sehingga antara pria dan wanita mendapatkan bagian secukupnya sesuai dengan fungsi dan tugasnya ada pria dan wanita. Di samping sifat-sifat hukum waris Islam mendapat warisan ialah :

1. Sebab ada hubungan per- kawinan;

2. Sebab ada hubungan turunan/ nasab;

3. Sebab ada hubungan agama orang yang meninggal dunia, apabila tidak ada ahli waris yang pasti, maka harta peninggalannya diserahkan kepada Baitulmal untuk umat Islam dengan jalan pusaka;

4. Sebab memerdekakan budak. Begitu pula diatur sebab-sebabnya seseorang tidak berhak mewaris yaitu :

1. Hamba atau budak.

Seorang hamba atau budak tidak mendapat pusaka dari sekalian keluarganya yang meninggal dunia selama is masih bersifat hamba.

2. Pembunuh, orang yang membunuh keluarganya tidak mendapat pusakadari keluarganya.

3. Murtat.

Orang yang keluar dari agama Islam tidak mendapat pusaka dari keluargnya yang masih tetap memeluk agama Islam, dan sebaliknya iapun tidak dipusakai oleh mereka yang 
masih beragama Islam.

4. Orang yang tidak memeluk agama Islam (kafir) yang berupa apapun kekafirannya, tidak berhak menerima pusaka dari keluarganya yang tidak memeluk agama Islam.

Dalam hukum waris Islam ini sebelum harta warisan dibagikan kepada ahli waris maka harus diperhitungkan lebih dahulu untuk pembayaran yang harus dilunasi oleh si peninggal, yakni :

1. Hutang piutang.

Sebagai imbangan dari hak yang telah diberikan oleh hukum kepada ahli waris untuk menerima pembagian harta warisan, para ahli waris berkewajiban membayar hutang dari yang meninggal kalau orang yang meninggal itu meninggalkan utang. Kalau utang dari orang yang meninggal itu lebih besar jumlahnya dari pada harta yang is tinggalkan, maka ahli warislah yang bertanggung jawab.

2. Zakat, yaitu membagi-bagikan harta pusaka kepada semua ahli waris menurut ketentuan hukum.

3. Wasiat, kalau orang yang telah meninggal dunia itu sebelumnya telah berwasiat tentang sesuatu, maka untuk melaksanakan wasiat itu menjadi kewajiban bagi para ahli waris.

4. Ongkos-ongkos untuk jenazah. Ongkos-ongkos untuk mengubur jenazah, sesuai dengan syaratsyarat penguburan mayat dan harus sesuai dengan aturan-aturan yang telah ditetapkan oleh hukum.

Setelah seluruh hal tersebut di atas dilaksanakan, barulah sisanya dibagibagikan kepada yang berhak.

Dengan masih ada dan berlakunya 3 (tiga) sistem hukum waris tersebut di atas, maka orang Indonesia yang beragama Islam dapat melakukan pilihan hukum yang akan digunakan dalam menyelesaikan dan membagi harta waris, dalam hal ini mereka dapat memilih hukum waris adat atau hukum waris Islam. Pilihan hukum bagi orang Indonesia yang beragama Islam ini hanya dapat dilakukan, apabila mereka mau menyelesaikan di luar lembaga peradilan, akan tetapi pilihan hukum itu tidak dapat dilakukan, apabila

Pilihan Hukum Waris Bagi Orang Di 280 
perkara sudah masuk di lembaga peradilan, hal ini dijelaskan pada Penjelasan Umum Undang-Undang Nomor 7 Tahun 1989 Tentang Peradilan Agama angka 2 alinea keenam, antara lain berbunyi "para pihak sebelum berpekara dapat mempertimbangkan untuk memilih hukum apa yang akan dipergunakan dalam pembagian warisan". Kalimat "sebelum perkara ini" dalam penjelasan ini dapat diartikan penyelesaian perkara di luar badan peradilan.

\section{Kewenangan Pengadilan Dalam Mengadili Perkara Waris}

Undang-Undang Dasar 1945 Amandemen IV (selanjutnya disebut UUD 1945) dalam Pasal 24 menyebutkan

(1) Kekuasaan kehakiman merupakan kekuasaan yang merdeka untuk menyelenggarakan peradilan guna menegakan hukum dan keadilan.

(2) Kekuasaan kehakiman dilakukan oleh sebuah Mahkamah Agung dan badan peradilan yang berada dibawahnya dalam lingkungan peradilan umum, lingkungan peradilan agama, lingkungan peradilan militer, lingkungan peradilan tata usaha negara, dan oleh sebuah Mahkamah Konstitusi.

(3) Badan-badan lain yang fungsinya berkaitan dengan kekuasaan kehakiman diatur dengan undang-undang.

Dari bunyi pasal 24 UUD 1945 itu, maka untuk merealisasi ketentuan tersebut lahirlah Undang-Undang Nomor 4 Tahun 2004 Tentang Kekuasaan Kehakiman (selanjutnya di sebut UU No.4 Tahun 2004) yang mencabut UndangUndang Nomor 35 Tahun 1999 Tentang Perubahan Undang-Undang Nomor 14 Tahun 1970 Tentang Ketentuan Pokok Kekuasaan Kehakiman. Undang-Undang Nomor 4 Tahun 2004 Pasal 10 ayat (1) dan ayat (2) berbunyi :

(1) Kekuasaan Kehakiman dilakukan oleh sebuah Mahkamah Agung dan badan peradilan yang berada dibawahnya dan oleh sebuah Mahkamah Konstitusi.

(2) Badan Peradilan yang berada di bawah Mahkamah Agung meliputi badan peradilan dalam 
lingkungan Peradilan Umum, Peradilan Agama, Peradilan Militer dan Peradilan Tata Usaha Negara.

Ketentuan yang mengatur kewenangan dalam lingkungan Peradilan Umum diatur oleh Undang-Undang Nomor 8 Tahun 2004, dimana yang berkaitan dengan kewenangan Peradilan Umum ini diatur dalam Pasal 50 yang berbunyi : "Peradilan Umum bertugas dan berwenang memeriksa, memutuskan perkara pidana dan perkara perdata".

Dari bunyi pasal tersebut diatas, dapatlah ditafsirkan yang dimaksud dengan perkara perdata tentunya salah satunya adalah perkara waris. Untuk pelaksanaannya, peradilan tingkat pertama dilaksanakan oleh Pengadilan Negeri yang berkedudukan pada Kota dan Kabupaten dan Peradilan Tingkat banding dilakukan oleh Pengadilan Tinggi yang tempat kedudukan di Ibu Kota Propinsi serta Mahkamah Agung sebagai puncak peradilan tertinggi dilingkungan Perdilan Umum.

Peradilan Umum sebagai badan peradilan bagi rakyat jangkauan fungsi dan kewenangannya meliputi bidang perkara pidana dan perkara perdata serta perkara-perkara yang tidak bisa dijangkau oleh peradilan khusus yaitu Peradilan Agama, Peradilan Militer dan Peradilan Tata Usaha Negara, namun hal ini tidak berarti Peradilan Umum berada diatas lingkungan yang lain.

Kewenangan yang diberikan kepada Peradilan Agama berdasarkan UndangUndang Nomor 7 Tahun 1989, seperti yang termuat dalam Pasal 49 dan Pasal 50 yang berbunyi : Pasal 49

(1) Pengadilan Agama bertugas dan berwenang memeriksa, memutus dan menyelesaikan perkara-perkara ditingkat pertama antara orangorang yang beragama Islam dibidang :

a. Perkawinan,

b. Kewarisan, wasiat dan hibah yang dilakukan berdasarkan hukum Islam,

c. Wakaf dan Shodaqoh.

(2) Bidang perkawinan sebagaimana yang dimaksud dalam ayat (1) huruf a, ialah hal-hal yang diatur dalam atau berdasarkan UndangUndang mengenai perkawinan yang berlaku.

(3) Bidang kewarisan sebagaimana yang dimaksud dalam ayat (1) huruf $b$, ialah penentuan siapa-siapa yang menjadi ahli waris, penentuan 
mengenai harta peninggalan, penentuan bagian masingmasing ahli waris dan melaksanakan pembagian harta peninggalan tersebut.

Pasal 50

Dalam hal terjadi sengketa mengenai hak milik atau keperdataan lain dalam perkara-perkara sebagaimana yang dimaksud dalam pasal 49, maka khusus mengenai obyek yang menjadi sengketa tersebut harus di putus lebih dahulu oleh pengadilan dalam lingkungan peradilan umum.

Kekuasaan kehakiman dilingkungan Peradilan Agama dalam Undang-Undang Nomor 7 Tahun 1989 dilaksanakan oleh Pengadilan Agama dan Pengadilan Tinggi Agama yang berpuncak pada Mahkamah Agung sesuai prinsip yang ditentukan oleh Undang-Undang Nomor 4 Tahun 2004 Tentang Kekuasaan Kehakiman.

Pengadilan Agama merupakan pengadilan tingkat pertama untuk memeriksa, memutus dan menyelesai-kan perkara-perkara antara orang-orang yang beragama Islam dibidang perkawinan, kewarisan, wasiat, hibah, wakaf dan shodaqoh berdasarkan hukum Islam. Di bidang kewarisan adalah mengenai penentuan siapa-siapa yang menjadi ahli waris, penentuan harta peninggalan, penentuan masingmasing ahli waris dan pelaksanaan harta peninggalan tersebut, bilamana pewarisan tersebut dilakukan berdasarkan hukum Islam. Sehubungan dengan hal tersebut, para pihak sebelum berperkara dapat mempertimbangkan untuk memilih hukum apa yang akan dipergunakan dalam pembagian warisan.

Dari apa yang diuraikan diatas dari penjelasan umum UndangUndang Nomor 7 Tahun 1989 Tentang Peradilan Agama, angka 2, apabila penyelesaian ini dibaca secara harfiah, maka akan membuat kabur dan lemahnya pelaksanaan UndangUndang Nomor 7 Tahun 1989 Tentang Peradilan Agama serta akan menimbulkan ketidakpastian hukum, khususnya bagi orang-orang yang beragama Islam dibidang kewarisan.

Kewenangan Peradilan Militer diatur dalam Undang-Undang Nomor 31 Tahun 1997, Pengadilan dan Oditur dilngkungan Peradilan Militer mempunyai kewenangan mengadili perkara pidana juga mempunyai kewenangan memeriksa memutus dan menyelesaikan Sengketa Tata Usaha 
Angkatan Bersenjata. Selain itu pula pengadilan dan Odatur Militer merupakan sarana pembinaan prajurit secara organisatoris, administratif dan finasial dibawah Mahkamah Agung.

Kewenangan Peradilan Tata Usaha Negara diatur dalam Undang-Undang Nomor 9 Tahun 2004 Tentang Perubahan Atas Undang-Undang Nomor 5 Tahun 1986, Peradilan Tata Usaha Negara merupakan salah satu pelaksana kekuasaan kehakiman yang ditugasi untuk memeriksa, memutus dan menyelesaikan sengketa dalam bidang Tata Usaha Negara, kecuali sengketa tata usaha dilingkungan Angkatan Bersenjata.

Sengketa Tata Usaha Negara, merupakan sengketa yang timbul dalam bidang tata usaha negara antara orang atau badan hukum perdata dengan Badan atau Pejabat Tata Usaha Negara sebagai akibat dikeluarkannya suatu Keputusan Tata Usaha Negara yang dianggap melanggar hak orang atau badan hukum perdata. Dengan demikian Peradilan Tata Usaha Negara itu diadakan dalam rangka memberikan perlindungan kepada rakyat pencari keadilan, yang merasa dirinya dirugikan akibat suatu keputusan Putusan Tata
Usaha Negara.

\section{PILIHAN HUKUM WARIS BAGI ORANG INDONESIA BERAGAMA ISLAM}

Dengan diaturnya masing-masng kewenangan absolud dari badan peradilan diharapkan tidak terjadi benturan kewenangan dalam menangani perkara, akan tetapi dalam kenyataannya masih terjadi, yaitu tidak sinkronnya Pasal 49 ayat (1) Undang-Undang Nomor 7 Tahun 1989 Tentang Peradilan Agama dengan Pasal 50 UndangUndang Nomor 8 Tahun 2004 Tentang Peradilan Umum, dalam hai menyelesaikan perkara waris. Hal ini dikarenakan di Indonesia belum ada satu unifikasi dibidang hukum waris, karena sampai saat ini masih berlaku 3 (tiga) sistem hukum waris yaitu ; hukum waris menurut hukum Perdata barat, hukum waris menurut hukum adat dan hukum waris menurut hukum Islam.

Penyelesaian konflik kewenanangan mengadili perkara warisan bagi orang Indonesia yang beragama islam antara pengadilan agama yang berdasarkan Undang-Undang Nomor 7 Tahun 1989 dengan Pengadilan Negeri yang berdasarkan Undang-Undang Nomor 8 
Tahun 2004 dapat dikembalikan pada pedoman secara normatif yaitu UndangUndang Nomor 5 Tahun 2004 Tentang Perubahan Atas UndangUndang Nomor 14 Tahun 1985 Tentang Mahkamah Agung pasal 33 ayat (1) yang berbunyi : Mahkamah Agung memutus pada tingkat pertama dan terakhir semua sengketa tentang kewenangan mengadili.

Berdasarkan pasal 57 UndangUndang Mahkamah Agung tersebut diatas permohonan untuk memeriksa dan memutus sengketa kewenangan mengadili dalam perkara perdata waris diajukan secara tertulis kepada Mahkamah Agung disertai pendapat dan alasannya oleh para pihak yang berperkara melalui ketua pengadilan atau oleh ketua pengadilan yang memeriksa perkara tersebut. Setelah perkara diterima dan didaftar oleh panitera Mahkamah Agung, maka pihak lawan yang berperkara akan menerima salinan dan dalam waktu 30 hari setelah menerima salinan permohonan tersebut is berhak mengajukan jawaban tertulis ke Mahkamah Agung disertai jawaban dan alasanalasannya. Selama pemeriksaan oleh Mahkamah Agung pemeriksaan perkara ditunda sampai sengketa tersebut di putus oleh Mahkamah Agung, apabila sudah di putus oleh Mahkamah Agung, maka putusan disampaikan kepada para pihak dan ketua pengadilan yang bersangkutan.

Mahkamah Agung dalam memutus konflik kewenangan mengadili dapat berpedoman pada asas hukum yang dapat menjadi pegangan bagi praktisi hukum, yaitu asas Lex specialis derogat generalis dimana pengertian asas ini ialah, hukum yang bersifat khusus menggeser kedudukan hukum yang bersifat umum. Undang-Undang Nomor 7 Tahun 1989 Tentang Peradilan Agama adalah undang-undang yang bersifat khusus, karena dipermasalahkan bagi orang-orang yang beragama Islam, sedangkan Undang-Undang Nomor 8 Tahun 2004 Tentang Peradilan Umum adalah undang-undang bersifat umum, karena disediakan bagi semua jenis perkara pidana dan perdata tanpa ada ketentuan mengenai agama bagi para pencari keadilan. Berpedoman pada asas Lex specialis derogat Lex generalis, maka kewenangan Pengadilan Agama untuk mengadili perkara waris bagi orang Islam dapat menyisihkan kewenangan Pengadilan negeri. 
Selain berpedoman pada asas hukum Lex specialis derogat Lex generalis Mahkamah Agung dapat berpedoman pada Pasal 49 ayat (1) Undang-Undang Nomor 7 Tahun 1989 berwenang memeriksa, memutus dan menyelesai-kan perkara antara orangorang yang beragama Islam dibidang kewarisan. Dalam pasal 49 ayat (1) kaidah Islam melekat pada pasal ini, maka dapat dijadikan dasar untuk menyelesaikan persoalan waris bagi orang Islam dengan menggunakan kaidah-kaidah hukum Islam. Selain itu Pula ada Surat Edaran Mahkamah Agung Nomor 2 Tahun 1990 ditujukan kepada Para Ketua Pengadilan Tinggi, Para Ketua Pengadilan Negeri dan Para Ketua Pengadilan Tinggi Agama serta Para Ketua Pengadilan Agama, dimana dalam angka ke 5 (lima) Surat Edaran berbunyi : Perkara warisan yang terjadi antara pihak-pihak yang beragama Islam, yang diajukan ke Pengadilan Negeri sebelum 1 Juli 1990 tetap diperiksa, diputus oleh Peradilan Umum.

Dari bunyi surat edaran tersebut diatas dapat diartikan, bahwa sejak 1 Juli 1990 perkara warisan bagi orang Indonesia yang beragama Islam menjadi kewenangan Peradilan Agama atau sejak 1 Juli 1990 Pengadilan Negeri dilarang menerima perkara waris bagi pihak-pihak yang beragama Islam.

Surat edaran Mahkamah Agung fungsinya adalah sebagai bentuk pembinaan teknis Mahkamah Agung kepada para hakim dilingkungan semua peradilan sehingga surat edaran ini dapat dipakai sebagai pedoman bagi para hakim didalam melaksanakan fungsi kehakiman tanpa mengurangi kebebasan para hakim didalam mengambil keputusan.

\section{PENUTUP}

Dengan berpedoman pada pasal 33 ayat (1) Undang-Undang Nomor 5 Tahun 2004, Tentang Perubahan atas Undang-Undang Nomor 14 Tahun 1985 Tentang Mahkamah Agung, Pasal 49 ayat (1) UndangUndang Nomor 7 Tahun 1989 dan asas hukum Lex specialis derogat Lex generalis serta komsistensi Mahkamah Agung terhadap Surat Edaran Mahkamah Agung Nomor 2 Tahun 1990 angka 5, maka Mahkamah Agung didalam memutus sengketa kewenangan mengadili perkara waris bagi orang Indonesia yang beragama Islam, seharusnya kewenangan tersebut diberikan kepada Peradilan 
Agama.

\section{DAFTAR PUSTAKA}

Abdullah, Siddik, Hukum Waris Islam dan Perkembangannya di seluruh Dunia Dalam, Wijaya, Jakarta, 1984.

Achmad Rustandi dan Muchjidin Efendi, Komentar Atas undangUndang Nomor 7 Tahun 1989 Tentang Peradilan Agama, Unimus, Bandung, 1991.

Afdol, Penerapan Hukum Waris Islam Secara Adil, Airlangga University Press, Surabaya, 2003.

Afdol, Landasan Hukum Positip Pemberiakuan Hukum Islam dan Permasalahan Implementasi Hukum Kewarisan Islam, Airlangga University Press, Surabaya, 2003.

Ahmad Kamil dan M. Fausan, KaidahKaidah Hukum Yurisprudensi, Kencana, Jakarta, 2004.

AH. Daud, Hukum Islam Pengantar IImu Hukum dan Tata Hukum di Indonesia, Raja Grafindo Persada, Jakarta, 2001.

A. Rasyid, Raihan, Hukum Acara Peradilan Agama, Raja Grafindo Persada, Jakarta,
1996.

Budiono, A Rachmad, Pembahasan Hukum Kewarisan Islam di Indonesia, Citra Aditya Bhakti, Bandung, 1999.

Djamali, Abdul, Hukum Islam Berdasarkan Ketentuan Kurikulum Konsorsium IImu Hukum, Mandar Maja, Bandung, 2002.

Harahap, Yahya, Kedudukan Kewenangan dan Acara Peradilan Agama, Pustaka Kartini, Jakarta, 1993.

Hadi Kusumo, Hilman, Hukum Waris Indonesia Menurut Pemndang-Undangan, Hukum Adat, Hukum Agama Hindu dan Islam, Aditya Bhakti, Bandung, 1991.

Hadi Kusumo, Hilman, Hukum Waris Adat, Aditya Bhakti, Bandung, 1993.

Otje Salamon dan Mustafa Haffas, Hukum Waris Islam, Rafika Aditama, Bandung, 2002.

Pitlo, A dalam Isa Marief, Hukum Waris Menurut Kitab UndangUndang Hukum Perdata Belanda, Internusa, Jakarta, 1979.

Pohon, M. Hukum Waris, Djumadi, Surabaya, 1981.

Projodikoro, Wirjono, Hukum Warisan Indonesia, Sumur, Bandung, 1976.

Salim Oemar, Dasar-Dasar Hukum 
Waris di Indonesia, Rineka Cipta, Jakarta, 2000, h.2.

Somardi, A Sukris, Transendeksi Keadilan Hukum Waris Islam Transformatif, Raja Grafindo Persada, Jakarta, 1997.

Soekanto, Soerjono, Pengantar Penelitian Hukum Universitas Indonesia Press, Jakarta, 1986.

Soepomo, Bab-Bab Tentang Hukum Adat, Pradnya Paramita, Jakarta, 1994. Subekti, Pokok-Pokok Hukum Perdata, Internusa, Jakarta, 1984.

Subekti dan Tjitro Sudibyo, Kitab Undang-Undang Hukum Perdata, Pradnya Paramita, Jakarta, 1992.

Sukini Alham Syarif dan Nurul E, Hukum Kewarisan Perdata Barat, Fakultas Hukum UI, Jakarta, 2005.

Tamakiran S, Asas-Asas Hukum Menurut Tiga Sistem Hukum, Pionir Jaya, Bandung, 2004.

Terhar, Asas-Asas Hukum Adat, Pradnya Paramita, Jakarta, 2001.

Wignyodipoero, Soepoyo, Pengantar Dan Asas-Asas Hukum Adat, Gunung Agung, Jakarta, 1995.

\section{Peraturan Perundangan :}

\section{Amandemen IV}

- $\quad$ Undang-Undang Nomor 4 Tahun 2004 Tentang Kekuasaan Kehakiman

- $\quad$ Undang-Undang Nomor 5 Tahun 2004 Tentang Perubahan Atas UndangUndang Nomor 14 Tahun 1985 Tentang Mahkamah Agung

- $\quad$ Undang-Undang Nomor 8 Tahun 2004 Tentang Perubahan Undang-Undang Nomor 2 Tahun 1986 Tentang Peradilan Umum

- Undang-Undang Nomor 31 Tahun 1997 Tentang Pengadilan Dan Oditur Dilingkungan Peradilan Mititer

Undang-Undang Nomor 7 Tahun 1989 Tentang Peradilan Negara

Undang-Undang Nomor 1 Tahun 1974 Tentang Perkawinan

Undang-Undang Nomor 9 Tahun 2004 Tentang Perubahan Atas UndangUndang Nomor 5 Tahun 1986 Tentang Peradilan Tata Usaha Negara

Yuridis Prudensi Mahkamah Agung RI No : 1615 K/Pdt/1993 Tentang Waris No : 30 K/Pdt/1995 Tentang Waris No : $53 \mathrm{k} / \mathrm{Pdt} / 1995$ Tentang Waris

- Surat Edaran Mahkamah Agung No. 2 tahun 1990 tentang Petunjuk Pelaksanaan Undang-Undang Nomor 7 Tahun 1989

- Inpres No. 1 Tahun 1991 Tentang Kompilasi Hukum Islam

- Undang-Undang Dasar 1945

\begin{tabular}{llll}
\hline \hline $\begin{array}{l}\text { Pilihan Hukum Waris Bagi } \\
\text { Indonesia Beragama Islam }\end{array}$ & Orang & 288 & Bambang Yunarko
\end{tabular}

